\title{
Prenatal perineal findings and possible clinical scenario
}

\author{
V. Oshovskyy, N. Antonenko \\ «Uniklinika» Medical center, Kyiv
}

The fetus's perineal area has not traditionally been the focus for the prenatal echoscopy, mainly because adequate visualization depends on fetus's position. However, it is precisely thanks to the targeted attention to the perineal area that we sometimes manage to find not only quite curious but clinically significant findings.

Sacrococcygeal teratoma can grow large and affect the natural birth process. When localized in the perineal region, it sometimes leads to defecation and micturition disorders. In addition, intestinal loops may be located in the tumor structure, which leads to deformation and the risk of hernia formation. In the presence of a giant sacrococcygeal teratoma, the following events may occur: heart failure leading to fetal hydrops, obstruction of the urinary tract, obstruction of the gastrointestinal tract, impaired innervation of organs due to compression, intratumoral hemorrhage, intrauterine anemia.

Hymenal pathology is quite rare in everyday clinical practice. Usually, it is one of the two most common nosologies: hymenal polyp or imperforate hymen. These two anomalies occur almost exclusively in childhood or immediately after menarche.

At a later age, the preserved or dysmorphic hymen can present difficulties in diagnosing and treating intravaginal pathological processes. In this article, we would like to bring to your attention two clinical cases with different prognosis to draw colleagues' attention to the need for a targeted assessment of the perineal area and correct prenatal counseling for a couple, because the ranking of the severity of the probable consequences is significant. Thus, some findings will require only adequate monitoring in childhood, others - may be the cause of premature birth, changes in delivery tactics or immediate surgery after birth.

Key words: prenatal diagnosis, sacrococcygeal teratoma, hymen polyp.

\section{Пренатальні перинеальні знахідки та можливі клінічні сценарії В.І. Ошовський, Н.М. Антоненко}

Зона промежини плода традиційно не в пріоритетному фокусі пренатолога багато в чому через те, що адекватна візуалізація залежить від положення дитини. Однак саме завдяки прицільній увазі до зони промежини іноді вдається виявити не тільки досить цікаві, але і часом клінічно важливі знахідки.

Крижово-куприкова тератома може досягати великих розмірів і перешкоджати нормальному народженню дитини. У разі локалізації у ділянці промежини вона іноді призводить до порушення акту дефекації і сечовипускання. Крім того, у структурі пухлини можуть знаходитися петлі кишечника, що спричинює деформацію і небезпеку утворення грижі. За наявності гігантської крижово-куприкової тератоми можуть виникати: серцева недостатність, що призводить до водянки плода, обструкція сечовивідних шляхів та травного тракту, порушення іннервації органів внаслідок компресії, внутрішньопухлинний крововилив, внутрішньоутробна анемія.

Гіменальну патологію діагностують досить рідко в повсякденній клінічній практиці. Зазвичай це одна з двох найбільш поширених нозологій: поліп гімена або неперфорована дівоча пліва. Ці дві аномалії виявляють майже виключно у дитинстві або відразу після менархе. У більш пізньому віці збережена або змінена дівоча пліва може представляти труднощі для діагностики і лікування інтравагінальних патологічних процесів.

У даній статті представлено два клінічних випадки з різним прогнозом, щоб привернути увагу колег до необхідності прицільного оцінювання зони промежини і коректного пренатального консультування пари, оскільки ранжування тяжкості ймовірних наслідків $є$ значним. Так, деякі знахідки вимагатимуть лише адекватного спостереження у дитячому віці, інші - можуть стати причинами передчасного розродження, зміни тактики ведення пологів чи негайного оперативного втручання після народження.

Ключові слова: пренатальна діагностика, крижово-куприкова тератома, поліп гімена.

\section{Пренатальные перинеальные находки и возможные клинические сценарии В.И. Ошовский, Н.Н. Антоненко}

Зона промежности плода традиционно не в приоритетном фокусе пренатолога во многом из-за того, что адекватная визуалиция зависит от положения ребенка. Однако именно благодаря прицельному вниманию к зоне промежности иногда удается обнаружить не только довольно любопытные, но и порой клинически важные находки.

Крестцово-копчиковая тератома может достигать больших размеров и препятствовать нормальному рождению ребенка. При локализации в области промежности она иногда приводит к нарушению акта дефекации и мочеиспускания. Кроме того, в структуре опухоли могут находиться петли кишечника, что приводит к деформации и опасности образования грыжи. При наличии гигантской крестцово-копчиковой тератомы могут возникать: сердечная недостаточность, приводящая к водянке плода, обструкция мочевыводящих путей и пищеварительного тракта, нарушение иннервации органов вследствие компрессии, внутриопухолевое кровоизлияние, внутриутробная анемия. Гименальную патологию диагностируют довольно редко в повседневной клинической практике. Обычно это одна из двух наиболее распространенных нозологий: полип гимена или неперфорированная девственная плева. Эти две аномалии выявляют почти исключительно в детстве или сразу после менархе. В более позднем возрасте сохранившаяся или измененная девственная плева может представлять трудности для диагностики и лечения интравагинальных патологических процессов.

В данной статье представлены два клинических случая с разным прогнозом, чтобы привлечь внимание коллег к необходимости прицельной оценки зоны промежности и корректного пренатального консультирования пары, поскольку ранжирование тяжести возможных последствий является значительным. Так, некоторые находки требуют только адекватного наблюдения в детском возрасте, другие - могут стать причинами преждевременного родоразрешения, изменения тактики ведения родов или немедленного оперативного вмешательства после рождения.

Ключевые слова: пренатальная диагностика, крестиово-копчиковая тератома, полип гимена. 


\section{АКТ УАЛ ВН І ТЕ М И}

Perhaps the first question of future parents who came for prenatal ultrasound examination sounds familiar: "and who is there with us?". But we must admit that this particular zone should become a zone of echoscopic interest, especially when visualization is not perfect due to fetal position. Thanks to the focused attention to the perineal area, we sometimes manage to find not only quite curious but clinically significant findings. We would like to present some of them to your attention in this article.

\section{Case number 1.}

A woman with a physiologic pregnancy was referred to our clinic at 32-33 weeks of gestation. Ultrasound investigation in the first and second trimesters found no pathological fetal changes. In the third trimester, a single-chamber formation with anechoic homogeneous contents, without blood flow, sized $17 * 15$ $\mathrm{mm}$ was visualized in the perineal region between the anus and the labia (the genitals were developed according to the female type). This mass was not anatomically associated with either the bladder or the fetal spine (Fig. 1). Preliminary diagnosis: neoplasm in the perineal region, cystic teratoma?

The girl was born at 39-40 weeks via planned cesarean section. At three weeks old, an MRI was done, the conclusion: the formation of soft tissues of the perineum (cystic teratoma?). At the age of 3 months, two operations were performed sequentially:

I - radical removal of the cystic duplication of the rectum;

II - the imposition of a loop sigmoidostomy.

In records the «National Cancer Institute» noted: «mature cystic teratoid tumor". The child requires careful medical supervision, since small clusters of cell groups positive for NSE, S100 receptors (markers correlating with potential tumor recurrence) were determined in the tumor. At the age of 8 months, the III colostomy closure operation was performed. At the moment the girl is 2.5 years old and in general healthy.

\section{Review of the literature}

Teratoma (teratoma; Greek teras, terat [os] monster, deformity + -ōma; synonyms: complex tumor, embryoma, mixed teratogenic tumor, tridermoma, monodermoma, parasitic fetus) - a tumor consisting of several types of tissues derived from one or two or three germ layers, the presence of which is not characteristic of those organs and anatomical regions of the body in which it develops [1]. According to modern concepts, teratoma belongs to the group of germ cell neoplasms. Germ cell tumors develop from a pluripotent, highly specialized germ cell epithelium of the gonads, capable of undergoing somatic trophoblastic differentiation and being a histogenetic source of tumors of various structures, for example, testicular seminoma, ovarian dysgerminoma, embryonic cancer, chorionepithelioma, polyembryomas, and also teratomas neoplasms (tumors of more than one histological type) [2].

According to the literature, teratoma accounts for approximately one third of all tumors in childhood and $7 \%$ of tumors in adults [3]. Teratoma is more common in women than in men. At the same time, in women, teratoma is usually benign, while the male sex is associated with tumor malignancy in a greater number of cases. In children aged 4 months to 5 years, teratomas are malignant in $50-60 \%$ of cases.

The causes of teratomas are not fully established. The most common hypothesis is based on the phenomenon of «embryo in embryo», that is, a violation of the formation of one of the «fused» twins, as a result of which one of them becomes a «parasitic» embryonic mass. Another hypothesis is the primary impairment of embryo formation, in which the embryonic layers are displaced in the early stages of embryogenesis. The reason for this may be, among other things, chromosomal abnormalities that arise in the germ cells even before fertilization [2].

Like other germ cell tumors, teratoma can be primarily localized in the testes and ovaries, and also be located extragonadally.

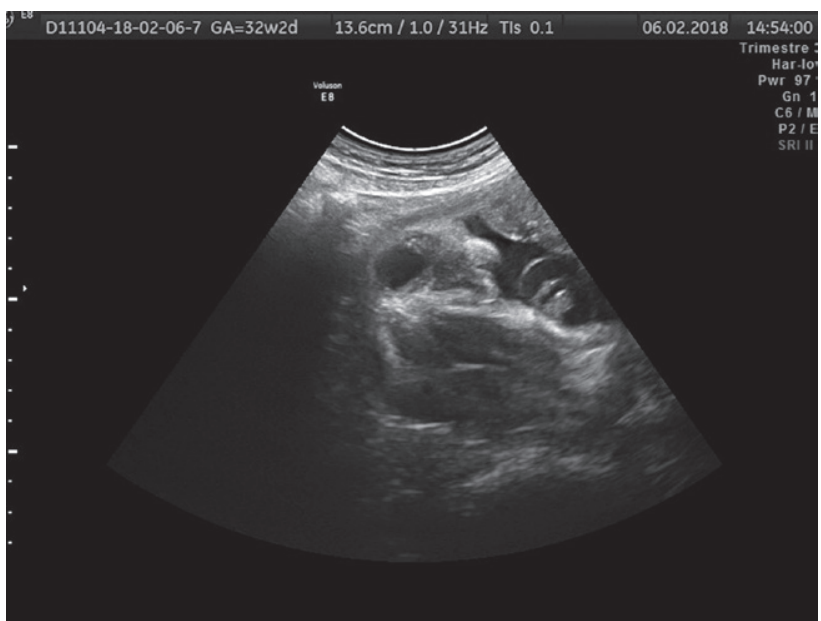

Fig. 1.

The appearance of a tumor outside the gonads is explained by the delay of the germ cell epithelium on the way of its migration from the yolk sac wall to the site of the gonad initiation at $4-5$ weeks of embryonic development [1,3].

The histological structure distinguishes between mature teratoma, immature teratoma, teratoma with malignant transformation [2, 4]. A mature teratoma consists of several mature, well-differentiated tissues derived from one, two, or three germ layers; it can be solid and cystic in structure. A mature teratoma of a solid structure (benign teratoma) is a dense tumor of various sizes, with a smooth or bumpy surface. On the cut, it is heterogeneous, represented in places by a heavy, whitish-gray tissue containing foci of cartilaginous and bone density, small cysts filled with transparent liquid or mucus [5]. A mature teratoma of a cystic structure is a tumor formation, as a rule, of large size, with a smooth surface. On the cut, the tumor is formed by one or more cysts filled with a cloudy gray-yellow liquid, mucus or mushy, greasy contents, in the lumen of the cysts there may be hair, teeth, fragments of cartilage.

Microscopically mature teratomas of solid and cystic structure do not differ significantly from each other. They consist of fibrous connective tissue, in which areas of well-differentiated mature stratified squamous epithelium, intestinal and respiratory epithelium, forming organoid structures, randomly alternate. Often there are structures of peripheral nerves, apocrine glands, bones, cartilage, teeth, brain tissue, adipose tissue, smooth muscles. Less commonly, tissue of the salivary gland, pancreas, adrenal gland, kidney, lung, breast can be found in the tumor. The vast majority of mature cystic teratomas are dermoid cysts [4].

A mature teratoma is a benign tumor and, as a rule, does not give metastases, although there are isolated reports of tumor implantation in the peritoneum with a ruptured ovarian teratoma.

An immature teratoma consists of immature tissues derived from all three germ layers, which resemble the embryo's tissues during organogenesis. The size of the tumor varies widely. It has an unevenly doughy consistency, grayish-white on the cut, with small cysts and mucous areas [5]. Microscopically, foci of proliferation of immature intestinal, respiratory, stratified squamous epithelium, immature striated muscles, cartilage are determined in the tumor. The presence of tissues of neuroectodermal origin in an immature teratoma is very characteristic. Among the immature elements of the embryonic type, there are tissue sites of a mature teratoma. It is generally accepted that an immature teratoma is a potentially malignant tumor $[5,6]$. Foci of malignant germ cell tumors in mature and immature teratomas, even with their small volume, largely determine the prognosis of the disease. 


\section{АКТ УАЛ В Н І Т Е М И}

Teratoma with malignant transformation is an extremely rare form of tumor. Its peculiarity lies in the appearance in a teratoma of a malignant tumor of the so-called adult type, such as squamous cell carcinoma, adenocarcinoma or melanoma. For example, cases of squamous cell carcinoma developed in a dermoid cyst have been described [1,3].

The clinical picture is determined mainly by the localization of the teratoma. Children more often than adults have their extragonadal forms. The localization of teratoid tumors in children is diverse:

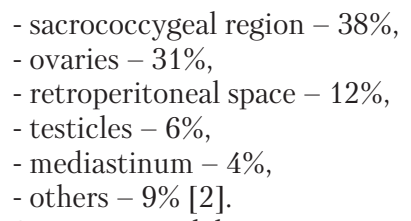

So, extragonadal teratomas are often observed in girls, mainly in the sacrococcygeal region.

Sacrococcygeal teratoma can grow large and affect the normal birth process. When localized in the perineal region, sacrococcygeal teratoma sometimes leads to a violation of the act of defecation and urination. In addition, intestinal loops may be located in the tumor structure, which leads to deformation and the risk of hernia formation.

In the presence of a giant sacrococcygeal teratoma, the following complications may occur: heart failure, leading to fetal hydrops, obstruction of the urinary tract, obstruction of the gastrointestinal tract, violation of the innervation of organs due to compression, intratumoral hemorrhage, intrauterine anemia.

The mortality rate among such fetuses is high, and averages $50 \%$. The most common cause of death is heart failure associated with volumetric overload of the heart, preterm labor due to polyhydramnios, bleeding after teratoma rupture, hypoxemia associated with anemia. In case of obstruction urinary tract tumor, oligohydramnios may occur, which leads to lung hypoplasia [5, 6].

As a rule, mediastinal teratoma, is localized in the anterior mediastinum; as it grows, it can protrude into one or another pleural cavity or the posterior mediastinum. For a long time, both sacrococcygeal and mediastinal teratomas may not manifest clinically and are detected by chance during X-ray examination. Retroperitoneal teratoma occurs mainly in children and often manifests itself in the same way as nephroblastoma or retroperitoneal neuroblastoma.

Treatment of mature and immature teratomas is operative. For teratomas combined with other malignant germ cell tumors, as well as for teratomas with malignant transformation, complex treatment is used. It includes surgical removal of the tumor, the use of anticancer drugs and radiation therapy [6].

The prognosis is determined by the histological structure's variant, the primary localization of the tumor, and timely and adequate treatment. The prognosis for teratoma, combined with embryonic cancer and chorionepithelioma, is the most unfavorable.

\section{Case №2.}

A woman with a physiologic pregnancy was referred to our clinic at 32-33 weeks of gestation. Ultrasound investigation in the first and second trimesters found no pathological fetal changes. In the third trimester, a small echogenic mass with a diameter of $2 \mathrm{~mm}$ was visualized in the area of the labia of the fetus (female genital organs) (Figure 2 in 2D mode), located closer to the posterior commissure of the vulvar ring (Figure 3 in $3 \mathrm{D}$ mode). No other fetal malformations were found. The girl was born naturally at 39-40 weeks. A polypoid formation was visualized in the labial area (Figure 4). Presumptive diagnosis: hymenal polyp. Observation by a gynecologist was recommended.

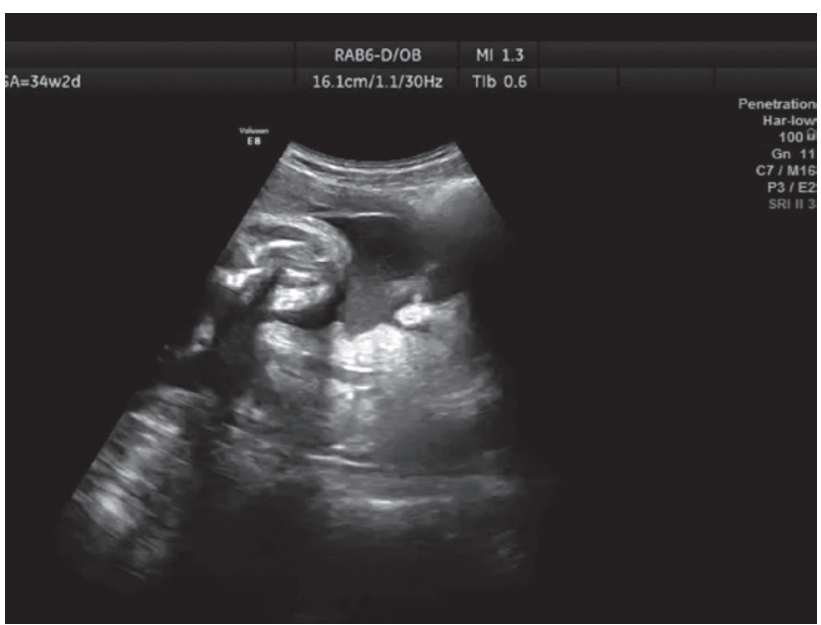

Fig. 2.

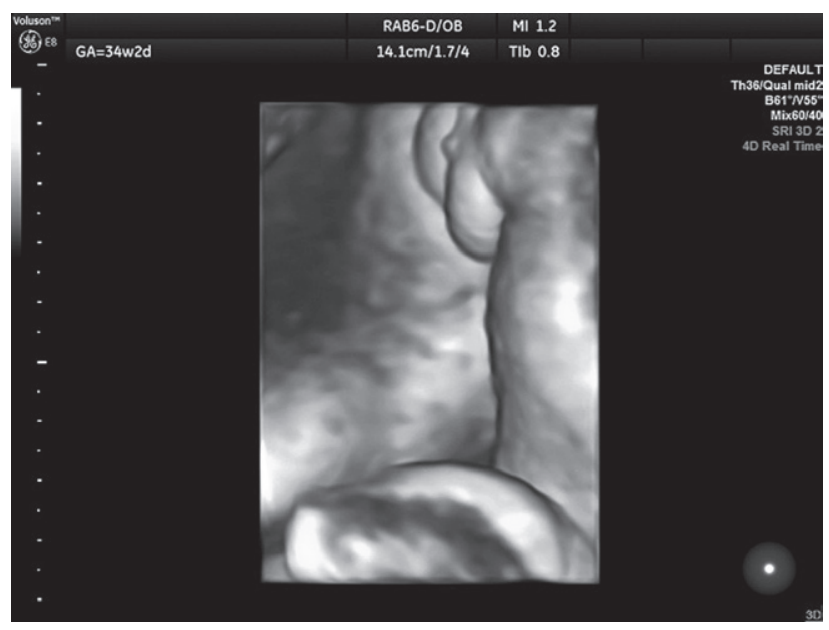

Fig. 3.

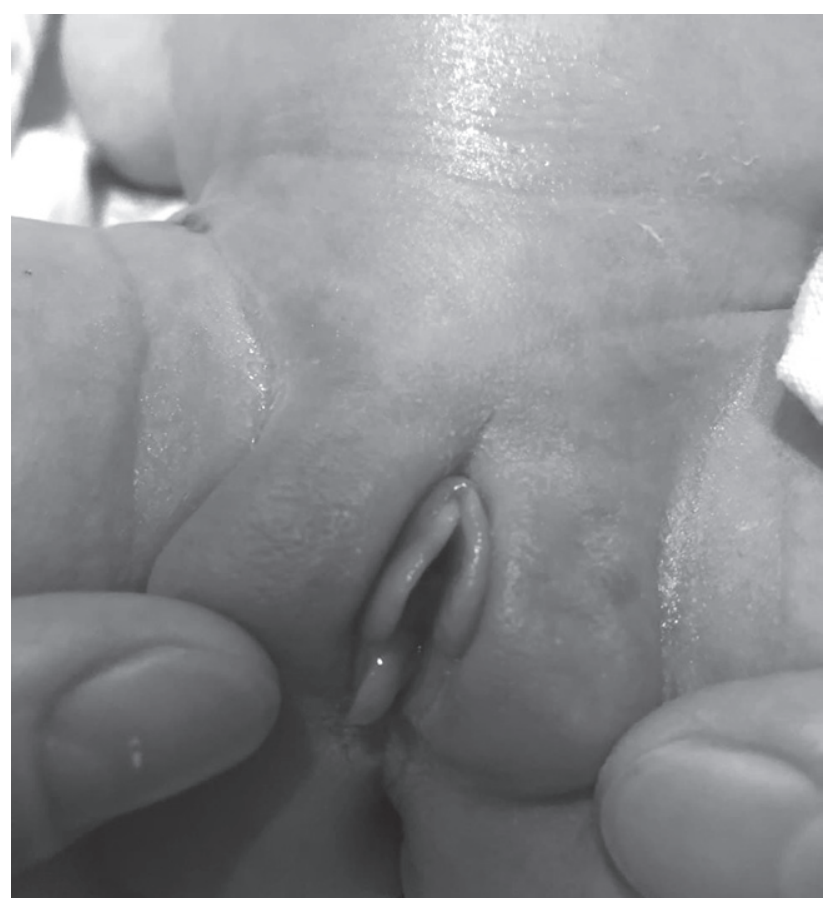

Fig. 4. 


\section{АКТ УАЛ ЬН І ТЕ М И}

\section{Review of the literature}

The hymen is a fold of the mucous membrane located between the vestibule and the vaginal cavity; it has a connective tissue base containing muscle fibers, nerves and blood vessels.

The hymen is formed at the end of the canal process of the vaginal plate in the fifth month of intrauterine development, and separates the canalized vagina from the urogenital sinus.

Hymenal pathology is quite rare in everyday clinical practice. Usually, it is one of the two most common nosologies: hymenal polyp or imperforate hymen. These two anomalies occur almost exclusively in childhood or immediately after menarche. At a later age, the preserved or dysmorphic hymen can present difficulties in diagnosing and treating intravaginal pathological processes.

Under the influence of maternal estrogens, the hymen of a newborn girl at birth and in the first days after it is thickened and edematous, and in some cases a round or oblong polyp is found in the back of it. Hymen polyp is a benign process. Hymenal polyps are not uncommon during neonatal and early childhood. Berglan and Selander found this anomaly in 6\% of the 1000 newborn girls examined. Their size is usually less than $5 \mathrm{~mm}$ and is probably due to estrogen stimulation during the prenatal period. Most polyps disappear by age 3 [7].
Microscopic (histological) description: fibrovascular tissue with overlying squamous cell epithelium.

Treatment is usually not required. Excision (hymen-sparing) may be considered in adolescents or young adult women to rule out other abnormalities or for cosmetic reasons.

Very rarely, they can persist and even increase in size (especially during adolescence, which may be due to an increase in estrogen levels at the beginning of puberty). In this case, the formations often cause an inflammatory reaction and sometimes spotting from the vagina. Then it will be rational to remove the polyp. In adult virgins, with pathological findings of the hymen or the vestibule of the vagina, there are recommendations for the excision and pathohistological examination of any neoplasms in order to exclude the remote possibility of a malignant process or any other intravaginal pathology that is difficult to investigate due to the intact hymen.

\section{CONCLUSION}

In this article, we aimed to draw the attention of colleagues to the need for a targeted assessment of the perineal area in any trimester and correct prenatal counseling for a couple as the ultrasound findings in the area are not so common but could be very important during the birth process and further in life.

\section{Information about the author}

Oshovskyy Victor I. - Medical center «Uniklinika», Department of Obstetrics, Gynecology and Fetal Medicine Shupyk National Healthcare University of Ukraine, 02000, Kyiv, Av. Heroiv Stalingrada, 4, b.4A. E-mail: pirhospr@gmail.com

Antonenko Natalia M. - Medical center «Uniklinika», 02000, Kyiv, Av. Heroiv Stalingrada, 4, b.4A. E-mail: antonenkonataliya09@gmail.com

\section{Відомості про авторів}

Ошовський Віктор Іванович - Медичний центр ТОВ «Уніклініка», кафедра акушерства, гінекології та медицини плода Національного університету охорони здоров’я України імені П.Л. Шупика, 02000, м. Київ, пр-т Героїв Сталінграда, 4, к.4а. E-mail:pirhospr@gmail.com

Антоненко Наталя Миколаївна - Медичний центр «Уніклініка», 02000, м. Київ, пр-т Героїв Сталінграда, 4, к.4а. E-mail: antonenkonataliya09@gmail.com

\section{Сведения об авторах}

Ошовский Виктор Иванович - Медицинский центр ООО «Униклиника», кафедра акушерства, гинекологии и медицины плода Национального университета здравоохранения Украины имени П.Л. Шупика, 02000, г. Киев, пр-т Героев Сталинграда, 4, к.4а.E-mail:pirhospr@gmail.com

Антоненко Наталья Николаевна - Медицинский центр ООО «Униклиника», 02000, г. Киев, пр-т Героев Сталинграда, 4, к.4а. E-mail: antonenkonataliya09@gmail.com

\section{REFERENCES}

1. «Тератомы различной локализации у детей», Н.Ш. Эргашев, Н.А. Дияров, Ф.М. Хуррамов, А.А. Рахматулаев, Д.С. Нурмаматов, 2016.

2. Дурнов Л.А, Опухоли удетей, М., 1982; Патологоанатомическая диагностика опухолей человека /Под ред. Н.А. Краевского и др. - М., 1982. - С. 298.
3. Журнал: SonoAce Ultrasound №27, Рубрика: Эхография в акушерстве, Мазырко M.A.

4. Arisoy R, Erdogdu E, Kumru P. Prenatal diagnosis and outcomes of fetal teratomas. J Clin Ultrasound. 2016 Feb; 44(2):118-25.

5. Hee Mang Yoon et.al. Sacrococcygeal teratomas in newborns: a comprehensive review for the radiologists, Acta Radiologica, 59, 2, (236), (2018).

6. Paradies G, Zullino F, Orofino A, Leggio $S$. Unusual presentation of sacrococcygeal teratomas and associated malformations in children: clinical experience and review of the literature. Ann Ital Chir. 2013 MayJun;84(3):333-46.

7. Mansouri J. Hymenal Pathology Outlines.com. http://www.pathologyoutlines. com/topic/vaginahymenal.html

8. Medicalplanet.su/ginecology/novoobrazovania_polovix_organov_novorogdennix.html 